\title{
THE SIDEROBLASTIC ANAEMIAS
}

\author{
J. J. Morrow, M.B., M.R.C.P.(Glas.), M.R.C.P. \\ A. GoldberG, M.D., M.R.C.P., F.R.C.P. (Glas.), F.R.C.P.Ed. \\ University Department of Medicine, Gardiner Institute, Western Infirmary, Glasgow, W.1.
}

THE SIDEROBLASTIC anaemias are a group of diseases in which the unique feature is the finding of 'sideroblasts' or iron-containing red cell precursors in the bone marrow, associated with anaemia in the peripheral blood. The anaemia is usually, but not always hypochromic. Indeed the diagnosis is often first suggested when a hypochromic anaemia has proved refractory to treatment with iron; but unlike iron deficiency anaemia the serum iron is often high and there are increased tissue iron stores. It is important to make this differentiation early since excessive iron is almost certainly harmful. Sideroblastic anaemia may occur as a primary isolated disorder with occasional evidence of a hereditary predisposition or it may be associated with chronic infections, carcinoma, collagen diseases or ingestion of certain drugs. The exact nature of the disease is unknown but in each type there is a disorder of haem biosynthesis in the bone marrow.

\section{The Sideroblast}

Prussian-blue staining granules were first recognised in the red blood cells by Bizzozero in 1883. Gruneberg (1941) found similar granules in the erythrocytes of normal mice, rats and man and called these cells siderocytes. Such cells were later found in the blood of patients who had undergone splenectomy (Doniach, Gruneberg and Pearson, 1943) and similar inclusion bodies were observed in human marrow normoblasts (Gruneberg, 1941; McFadzean and Davis, 1947; Dacie and Doniach, 1947). McFadzean and Davis observed that they were more numerous in patients with haemolytic anaemia than in normal subjects, and therefore regarded them as a sign of abnormal haemoglobin synthesis. Douglas and Dacie (1953) found siderotic granules in the erythroblasts of a large number of normal subjects and in a wide range of abnormal blood conditions but not in iron deficiency anaemia. They concluded that they were normal inclusions of developing erythroblasts although in cases of congenital hypochromic anaemia and refractory anaemia they considered that the abnormally large 8 granules were caused by defective haemoglobin 3 . synthesis. Kaplan, Zuelzer, and Mouriquand (1954) made similar observations in a large $\vec{P}$ number of children; they also noted the return of granules in the normoblasts of patients with iron deficiency anaemia treated with iron and 0 their appearance on addition of iron to cultures은 of iron deficient normoblasts.

The siderotic granules are small in the normalo subject and in conditions such as acquired and congenital haemolytic anaemia, megaloblastic 3 anaemia, myeloproliferative syndrome, leukaemia and related disorders. In these states the granules are usually not more than 5 or 6 ํㅐㅇ number and are distributed in the cytoplasî. with no definite relationship to the nucleus. Morse (1955) drew attention to the correlation of the number of sideroblasts with an elevatedo serum iron level and a high saturation of the iron binding capacity.

In the group of conditions now referred to $\overrightarrow{\vec{\theta}}$ as the sideroblastic anaemias there is character- $\frac{}{3}$ istic erythroid hyperplasia of the marrow often with a preponderance of basophilic cells in-o dicating maturation arrest. The proportion of cells containing siderotic granules is usually, 3 . but not always, increased and the granules are larger, coarser and more numerous in the individual cells and congregate in the peri-ô nuclear zone, forming a ring round the nucleus; $₹$ they are thus referred to as ring sideroblasts.음 Vacuolation of the cytoplasm of the normo- $\rightarrow$ blasts has also been described (Dacie, Smith, White and Mollin, 1959).

Kaplan and others (1954) introduced the $\mathrm{N}^{\mathrm{N}}$ term 'sideroblast' to indicate a normal red cell 0 precursor with visible iron-containing granules, but Mollin (1965) has applied the termo 'sideroblast' to the normal cell and 'abnormalo sideroblast' where pathological amounts of iron $\overparen{\varnothing}$ are present.

\section{Electron Microscopy}

Using the electron microscope Bessis and 
Breton-Gorius (1959) demonstrated that the iron in the granules of normal normoblasts and reticulocytes is in ferritin, scattered throughout the cytoplasm either as single ferritin molecules or as clusters. In the abnormal sideroblasts of sideroblastic anaemia they found a marked increase in non-haem iron which appeared in two forms; ferritin indistinguishable from normal and an abnormal form, amorphous and dustlike, to which they applied the term 'ferruginous micelles'. They located ferritin in the mitochondria as well as in the cytoplasm and ferruginous micelles only in mitochondria especially in the perinuclear zone. These mitochondria were disrupted and abnormal in structure. It has been suggested that the appearance of the ring sideroblast is due to the persistence of large numbers of viable and non-viable iron-laden mitochondria in their primitive perinuclear situation.

\section{Tissue Iron Stores in Sideroblastic Anaemia}

Tissue iron stores, mainly in the bone marrow and liver, are increased in sideroblastic anaemia. In the more severe cases, fully developed changes of haemochromatosis may develop (Losowsky and Hall, 1965; Verloop, Bierenega and Diezeraad-Njoo, 1962). Where large amounts of parenchymal iron are laid down in the liver no perinuclear distribution is found (Bessis and Caroli, 1959). Excess iron has also been found in pancreas, spleen, kidneys and gastric mucosa. Brain and Herdan (1965) found that the concentration of liver iron, but not marrow iron, was related to the amount of therapeutic iron or blood transfusion given; there was little hepatic iron in patients not so treated.

\section{Definition and Classification}

The sideroblastic anaemias may be defined as a group of diseases of multifactorial aetiology in each of which there is derangement in the final pathway of haem biosynthesis in the erythrocyte precursors giving rise to anaemia and characteristic ring sideroblasts in the bone marrow.

They may be divided into primary and secondary groups depending on whether the anaemia is the sole abnormality present or whether it occurs in the presence of another disease. Such a classification (Table 1) does not imply any morphological difference in the form of the sideroblasts present or the presence of any other haematological differentiating features.

\section{TABLE 1}

Classification of Sideroblastic Anaemias

Primary

(a) Congenital

1. Hereditary sex-linked anaemia (Rundles and Falls (1946)).

2. Familial hypochromic anaemia (Mills and Lucia (1949)).

3. Anaemia hypochromia, sideroachrestica hereditaria (Heilmeyer (1958)).

4. Hereditary sideroblastic anaemia (Lukl and others (1958); Losowsky and Hall (1965)).

(b) Acquired

1. Chronic refractory anaemia with sideroblastic bone marrow (Bjorkman (1956)).

2. Refractory normoblastic anaemia (Dacie and others (1959)).

Secondary

1. Anaemia associated with lead poisoning.

2. Anaemia associated with antituberculous drugs INAH, cycloserine, pyrazinamide.

3. Sideroblastic anaemia associated with : Carcinoma

Rheumatoid arthritis

Myeloproliferative diseases

Polyarteritis nodosa

Multiple myeloma

Hereditary and acquired haemolytic anaemia Leukaemia

Addisonian pernicious anaemia

\section{Primary (Idiopathic) Sideroblastic Anaemia}

\section{(1) Congenital Sideroblastic Anaemia}

Genetic Transmission. The number of cases of familial sideroblastic anaemia repcrted is small and in only two families have studies been extensive enough to reliably indicate the mode of inheritance. Losowsky and Hall (1965) studied 110 members of a family in four generations and found a varying degree of anaemia, peripheral hypochromia and abnormal ring sideroblasts in 10 . The pattern of inheritance showed a sex-linked partially recessive character; all but one of the anaemic subjects were males. Some female carriers showed typical red cell changes but in only one of these was anaemia present. The family studied by Lukl, Weiderman and Barborik (1958) showed a similar mode of inheritance. Dacie (1954), Byrd and Cooper (1961), Verloop, Bierenga and Diezeraad-Njoo (1962) and Redmond, Robertson and Nelson (1963) also reported family studies in which the affected members were predominantly male.

Many cases of hereditary hypochromic anaemia have been reported which are probably examples of hereditary sideroblastic anaemia although sideroblasts in these cases were not specifically sought. Large familial studies by Cooley (1945) and Rundles and Falls (1946) indicate a sex linked inheritance. Several other 
studies (Mills and Lucia, 1949; Gelpi and Ende, 1958; and Ludin, 1957) report familial hypochromic anaemia but the genetic pattern is not clear although again there is a marked preponderance of males.

Age of Onset. The congenital type of sideroblastic anaemia usually appears in adolescence or early manhood, but the range is wide.

Clinical and Haematological Findings. Apart from pallor, clinical examination is usually uninformative. The spleen is seldom palpable but the liver may be palpable if there is marked haemosiderosis. Anaemia is usually of moderate degree with a low mean corpuscular haemoglobin concentration and normal mean corpuscular volume. There is marked hypochromia and a variable degree of dimorphism. Osmotic fragility of the red cells is diminished and by separating the two types of cell by centrifugation, it can be shown that the increased resistance lies in the apparently abnormal cells. The reticulocyte count is normal. The bone marrow shows marked erythroblastic hyperplasia usually but not always with large numbers of abnormal ring sideroblasts. Erythropoiesis is normoblastic in most cases but transitional megaloblastic changes have been described. The serum iron is usually raised and the iron binding capacity saturated.

Female carriers seldom show any haematological abnormality and when changes occur they are minimal, usually some degree of dimorphism and hypochromia with or without mild anaemia. Increased siderotic granulation of the normoblasts may be present but ring forms are scanty. The serum iron and percentage saturation of transferrin are usually normal.

\section{(2) Acquired Sideroblastic Anaemia}

Several cases of refractory anaemia have been described in patients without a hereditary background and some of these can probably be included in this group. In twelve cases of Bomford and Rhoads (1941) the marrow was termed as 'immature hypercellular' and in some of these iron was conspicuous. Bjorkman (1956) described four cases of refractory anaemia and hyperplasia of the marrow which contained normoblasts with siderotic granules and vacuoles. The serum iron was raised at some stage of the illness. One case died of acute myeloblastic leukaemia. Other cases of refractory anaemia with marrow sideroblasts have been reported by Heilmeyer, Keiderling, Belger and Bernauer (1958) and Dacie and others (1959).

Age and Sex Incidence. The anaemia usually appears in later life but the range is wide. Both sexes are affected with some preponderance of females.

Haematological Findings. The anaemia is usually of moderate severity and is normochromic and normocytic although a variable number of hypochromic microcytic cells are present. The reticulocyte count is normal. There may be leukopenia and occasionally thrombocytopenia. The erythrocyte osmotic fragility is normal. The bone marrow displays intense normoblastic hyperplasia and large numbers of abnormal sideroblasts: megaloblastic change has been found in a few cases. There is evidence of maturation arrest in the increased numbers of basophilic normoblasts present and defective haemoglobinisation is apparent in many cells. Many nuclei appear pyknotic and vacuolation of the cytoplasm of the normoblasts is conspicuous.

Serum iron and percentage saturation are usually normal but high iron levels and a saturated iron binding capacity may occur.

\section{Secondary Sideroblastic Anaemia}

The diagnosis of secondary sideroblastio anaemia depends on the coexistence of anothero disease along with the characteristic anaemia No morphological difference is apparent between the sideroblasts seen in the primary and? secondary types. MacGibbon and Mollin (1965) studied 35 cases of secondary sideroblastic anaemia associated with a wide range of diseases and in $75 \%$ of cases found the severity of the abnormalities to be as great as those seen in a group of primary sideroblastic anaemias. Differences between the two groups are mainly of degree but in secondary sideroblastic anaemia hypochromia is relatively uncommon, megaloblastic change more frequent and the serum iron level and percentage saturation of the iron binding capacity more variable.

\section{Sideroblastic Anaemia and other Diseases}

Sideroblastic anaemia has been found in association with chronic infections, neoplastic and collagen diseases and in a number of other conditions summarised in Table 1 . In many cases the anaemia was an unexpected finding in the general investigation of the patient. The diagnosis of secondary sideroblastic anaemia offers no difficulties where the associated disease is overt but where no such condition is obvious, a thorough search for latent neoplastic or collagen disease must be made. Drugs

Sideroblastic anaemia has been found in a small number of tuberculous patients under 
TABLE 2

Comparison of Congenital and Acquired Primary Sideroblastic Anaemia

\begin{tabular}{|c|c|c|}
\hline \multirow{5}{*}{$\begin{array}{l}\text { Age } \\
\text { Sex } \\
\text { Family History } \\
\text { Anaemia }\end{array}$} & \multirow{3}{*}{$\begin{array}{c}\text { Congenital } \\
\text { Mainly young }\end{array}$} & \\
\hline & & Acquired \\
\hline & & Later life \\
\hline & $\begin{array}{l}\text { Male } \\
\text { Present }\end{array}$ & $\begin{array}{l}\text { Male and Female } \\
\text { Absent }\end{array}$ \\
\hline & Hypochromic mainly & Dimorphic: variable \\
\hline \multirow{6}{*}{$\begin{array}{l}\text { MCHC } \\
\text { MCV } \\
\text { Reticulocytes } \\
\text { Marrow }\end{array}$} & Low & $\begin{array}{l}\text { hypochromia } \\
\text { Normal }\end{array}$ \\
\hline & Normal & Normal/high \\
\hline & Normal & Normal and occasionally raised \\
\hline & Hyperplastic normoblastic & Normoblastic or megaloblastic \\
\hline & Sideroblasts very numerous & Sideroblasts numerous \\
\hline & & $\begin{array}{l}\text { pyknotic } \\
\text { pysts vacuolated and }\end{array}$ \\
\hline \multirow{7}{*}{$\begin{array}{l}\text { Abnormal Hb } \\
\text { Osmotic fragility } \\
\text { Serum iron } \\
\text { TIBC (Total Iron-binding } \\
\text { Capacity) } \\
{ }^{51} \mathrm{Cr} \text { survival } \\
{ }^{59} \mathrm{Fe} \text { studies } \\
\text { Erythrocyte porphyrins } \\
\text { and precursors }\end{array}$} & Absent & Absent \\
\hline & Decreased & Slightly decreased \\
\hline & $\begin{array}{l}\text { High } \\
\text { Saturated }\end{array}$ & $\begin{array}{l}\text { Variable } \\
\text { Variable }\end{array}$ \\
\hline & Normal or slightly reduced & Normal or slightly reduced \\
\hline & Ineffectual erythropoiesis & Ineffectual erythropoiesis \\
\hline & $\begin{array}{l}\text { Protoporphyrin normal or } \\
\text { decreased }\end{array}$ & Protoporphyrin normal or \\
\hline & $\begin{array}{l}\text { Coproporphyrin increased } \\
\text { Delta amino laevulic acid } \\
\text { increased }\end{array}$ & $\begin{array}{l}\text { Coproporphyrin increased } \\
\text { Delta amino laevulic acid } \\
\text { increased }\end{array}$ \\
\hline
\end{tabular}

treatment with isoniazid and the newer antituberculous drugs cycloserine and pyrazinamide. Verwilghen, Reybrouk, Callens and Cosemans (1965), reported five such cases where withdrawal of either cycloserine or pyrazinamide resulted in cure of the anaemia. Isoniazidinduced anaemia has responded to pyridoxine (Redleaf, 1962; MoCurdy, 1963), although in these cases sideroblasts were not specifically sought.

\section{Lead Poisoning}

The anaemia of lead poisoning is partly haemolytic but there is also evidence of gross disturbance of haem synthesis (Dagg, Goldberg, Lochhead and Smith, 1965) and abnormal ring sideroblasts have been found in the bone marrow (Bessis and Jensen, 1965).

\section{Radioisotope Findings in Sideroblastic Anaemia}

In both the congenital and acquired forms of sideroblastic anaemia red cell survival measured by the radiochromium technique has been normal or only slightly reduced. The daily output of faecal urobilinogen and the decrease in free plasma haptoglobin (Verloop and others, 1962) are greater than can be accounted for by the minor degree of peripheral haemolysis. There is presumably a state of ineffectual erythropoiesis, that is, many of the red cells or their precursors are destroyed while still in the bone marrow or shortly after their release into the peripheral circulation.

Ferrokinetic studies have shown a rapid plasma iron clearance and increased plasma iron turnover, but gross impairment of iron utilisation. Losowsky and Hall (1965) found increased absorption of radioiron with increased iron storage in the liver and spleen in the hereditary form. Increased absorption of iron was not, however, found by Brain and Herdan (1965).

In the anaemia of lead poisoning, red cell survival is moderately reduced and radioiron studies reveal normal iron turnover and marked reduction of iron utilisation. These abnormalities resolve with treatment (Dagg, Goldberg, Lochhead and Smith, 1965).

\section{Differential Diagnosis}

1. Other refractory anaemias, e.g. the anaemia of chronic infection, uraemia and haemoglobinopathies can be differentiated from sideroblastic anaemia by marrow examination, biochemical investigations and by a search for abnormal haemoglobins.

2. Iron deficiency anaemia. Hypochromia is present in both iron deficiency anaemia and in sideroblastic anaemia particularly of the hereditary type. These can be easily differentiated by measurement of serum iron and iron binding capacity in addition to estimation of the iron content of the bone marrow. This simple differentiation is important in order to 
avoid the needless and potentially harmful administration of iron.

3. Erythraemic myelosis. The most difficult differential diagnosis is that from chronic erythraemic myelosis (Di Guglielmo's Disease). In this condition erythroblasts usually occur in the peripheral blood and multinucleated red cell precursors and myeloblasts are prominent in the bone marrow. Furthermore, the periodic acid Schiff reaction of the erythroblasts is usually more strongly positive than in sideroblastic anaemia (Verloop and others, 1962). Dameshek (1965) has drawn attention to the many morphological, histochemical, enzymic and radioisotopic similarities between the two conditions and has suggested that many cases of acquired sideroblastic anaemia are examples of early Di Guglielmo's Disease. The relationship of the two conditions, however, must await a clearer understanding of the fundamental abnormalities present.

\section{Treatment}

The management of primary sideroblastic anaemia is aimed at the effective treatment of the anaemia itself and the avoidance of tissue iron overload or its reduction if it is already present.

Fortunately, many. cases do not require treatment because the haemoglobin is spontaneously maintained at a reasonable level. In the more severe primary sideroblastic anaemias the most satisfactory response to pyridoxine is usually found in the hereditary group where a reticulocytosis and a rise of haemoglobin to normal levels may occasionally be attained. Satisfactory remission of the acquired anaemia may also occur with pyridoxine. Complete haematological remission is unlikely in either group. The dose of pyridoxine required varies widely. In the hereditary anaemia as little as $2 \mathrm{mg}$. daily may suffice. In general large doses ranging from 100-1,000 $\mathrm{mg}$. daily are necessary to maintain improvement. Further improvement may occur with the administration of folic acid, especially where megaloblastic change has occurred, but may also be seen in cases where such changes are not evident. Deficiencies of vitamin $\mathbf{B}_{12}$ and ascorbic acid may aggravate the anaemia and partial improvement will occur with their administration.

Where treatment with these agents has failed blood transfusion may become necessary, but because of the danger of haemosiderosis and of aggravating the fundamental defect in these anaemias, it should only be used when absolutely necessary.
Where anaemia is not severe excess iron may $\frac{2}{2}$ be removed by small frequent venesections and $\stackrel{\varrho}{c}$

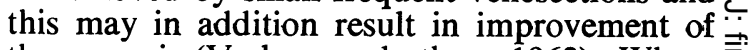
the anaemia (Verloop and others, 1962). Where $\overrightarrow{\vec{s}}$ anaemia is severe the only available means of $\overrightarrow{0}$ removing iron is by using chelating agents. 듬 Desferrioxamine is the most effective of these $\frac{\bar{c}}{\mathrm{~s}}$ at present but since the maximum daily loss $\overparen{\varnothing}$ is unlikely to exceed $20 \mathrm{mg}$. it is of limited value.

Secondary sideroblastic anaemia may resolve $\vec{\circ}$ with effective treatment of the primary disease $\overrightarrow{\vec{\omega}}$ and complete haematological remission can be expected. Other cases may respond completely $\vec{B}$ to combined pyridoxine and folic acid treatment (McGibbon and Mollin, 1965).

\section{Nature of the Disease}

The sideroblastic anaemias form such a heterogeneous group and their aetiological $\overrightarrow{0}$ associations are so diverse, that the question must be asked-what is the nature of these conditions? Are they primarily disorders of cellular growth of the marrow or dyscrasias of marrow porphyrin metabolism or inborn errors of metabolism or marrow defects induced b drugs or primary diseases? Or are the separate conditions, each with the commo pathological finding-the marrow sideroblast 5 . of

\section{Disturbance of Cell Growth in Marrow}

There are, of course, gross morphological changes in the bone marrow and often in the peripheral blood. In addition to a failure of haemoglobin synthesis, there is a state of ineffectual erythropoiesis. Dameshek (1965) has drawn attention to the similarities - clinical, haematological and possibly enzymic - between acquired sideroblastic anaemia and the chronic form of erythraemic myelosis (Di Guglielmo's disease); furthermore some cases of acquired sideroblastic anaemia have terminated as leukaemias (Bjorkman, 1956; Heilmeyer, 1964). These points underline the association of neoplastic processes with sideroblastic anaemia.

\section{Disorder of Porphyrin Metabolism}

One of the final steps in the formation of haemoglobin is the incorporation of iron into protoporphyrin by the enzyme haemsynthetase. In the sideroblastic anaemias there is not only evidence of accumulation of iron, but also of abnormalities in porphyrin metabolism in the red cells or their precursors. In hereditary sideroblastic anaemia erythrocyte protoporphyrin is normal or reduced and erythrocyte coproporphyrin and $\delta$-amino laevulic acid levels are raised, while in the acquired form there is 
an increase in coproporphyrin and $\delta$-amino laevulic acid but the protoporphyrin remains normal or is slightly raised (Garby, Sjolin and Vahlquist, 1957; Dacie and others, 1959; Heilmeyer, 1960; Heilmeyer and Clotten, 1961). There are thus enzymic defects early in the formation of porphyrin as well as at the final phase of iron incorporation into protoporphyrin. It is of interest that in the hereditary type there is not only an accumulation of $\delta$-amino laevulic acid and coproporphyrin, but also a more frequent response to pyridoxine therapy. In the family of Losowsky and Hall (1965) all affected members responded to pyridoxine, but there was no evidence of an abnormality in the enzyme which incorporates iron into protoporphyrin (haemsynthetase). Pyridoxal phosphate is responsible for the combination of glycine and succinyl $\mathrm{CoA}$ to form $\delta$-amino laevulic acid, and in addition it has been shown to be necessary for the mobilisation of iron from mitochondria (Cooper, Webster and Harris, 1963).

Lead causes a secondary sideroblastic anaemia and it mainly affects the phases of haem synthesis prior to $\delta$-amino laevulic acid formation and also the incorporation of iron into protoporphyrin (Goldberg, Ashenbrucker, Cartwright and Wintrobe, 1956; Lichtman and Feldman, 1963), but it probably also affects other intermediate phases of porphyrin synthesis. The direct measurement of haemenzymes in these diseases has so far proved inconclusive, mainly because of the technical problem of enzyme measurement in human marrow. Losowsky and Hall (1965) used a peripheral blood reticulocyte preparation in their studies which showed no abnormality of haemsynthetase activity, but Steiner, Baldini and Dameshek (1963) found a decrease in haemsynthetase and $\delta$-amino laevulic acid dehydrase in bone marrow aspirates, while Vavra (1964) using blood haemolysates found no evidence of impairment of porphyrinforming enzymes.

There are some findings which suggest that the intracellular accumulation of iron inhibits several stages of haem synthesis. Bishop and Bethel (1959) have suggested that the stage in haem synthesis where glycine is combined with succinyl $\mathrm{CoA}$, may be blocked by excessive iron forming an inactive complex with pyridoxine, which can only be overcome by large amounts of pyridoxine; drug-induced sideroblastic anaemia in guinea-pigs was aggravated by large doses of parenteral iron (Harriss, MacGibbon and Mollin, 1965).
Bessis and Jensen have demonstrated that it is the accumulation of ferritin in the mitochondria which is responsible for the appearance of 'ringed sideroblasts'. It has been shown that the mitochondria contain about $80 \%$ of the haemsynthetase activity in the fractionated hepatic cell of man and the rat (Lochhead and Goldberg, 1961) and that this intracellular constituent also plays an important part in other phases of haem synthesis such as the transformation of coproporphyrinogen to protoporphyrin. Ribosomes, which may also accumulate ferritin, play a notable part in globin synthesis. It is likely that any depression in globin synthesis in the sideroblastic anaemias is associated with, or possibly caused by abnormal haem synthesis, since the synthesis of haem and globin are closely linked (Rimington, 1958).

\section{Inborn Error of Metabolism}

There are thus enzymic defects early in the formation of porphyrins as well as at the final phase of iron incorporation into protoporphyrin. Although most of the cases of sideroblastic anaemia have failed to show a genetic background, in the rare hereditary form a sex-linked recessive type of inheritance has been demonstrated. This small group may, in the future conform to the definition of an inborn error of metabolism, but more definitive enzyme studies are required.

\section{Marrow Dyscrasia Induced by Diseases or Drugs}

Many of the examples of sideroblastic anaemia have been associated with primary diseases, such as neoplastic or collagen diseases, or with drug ingestion particularly the antituberculous drugs, especially INAH. An experimental sideroblastic anaemia has been described in guinea-pigs, intoxicated with INAH and cycloserine (Harriss and others, 1965). The mode of action of these drugs is uncertain, but it may be related to an interference with pyridoxine metabolism. Carlson (1956) found an increased urinary excretion of pyridoxine during INAH therapy and he suggested that the drug complexed with pyridoxine which was then excreted in the urine. It is unlikely, however, that pyridoxine deficiency alone causes sideroblastic anaemia, since Harriss and others (1965) failed to produce a characteristic sideroblastic anaemia in mice either by a pyridoxine free-diet or by the pyridoxine-inhibitor, deoxypyridoxine.

There is probably a more subtle association 
between the primary collagen and neoplastic diseases and sideroblastic anaemia. Anaemia itself is a usual complication of these diseases, and it is most unusual for this to take the form of a sideroblastic anaemia. Some patients afflicted with these conditions may have a latent hereditary defect predisposing them to develop sideroblastic anaemia. In others the ineffectual hyperplastic marrow, associated with the primary disease, may be profligate of its pyridoxine stores, causing a deficiency which would contribute to the development of sideroblastic anaemia.

It would seem therefore that the sideroblastic anaemias are a group of diseases multifactorial in pathogenesis, but each with the final common pathway of deranged haem synthesis in the bone marrow which results in the formation of the sideroblast. From this definition the sideroblastic anaemias bear some resemblance to the hepatic porphyrias, which are a group of diseases also multifactorial in pathogenesis, each with a final pathway of deranged haem synthesis in the liver. Thus in both the sideroblastic anaemias and in the hepatic porphyrias a disease exists which is caused by an inborn error of metabolism-hereditary sideroblastic anaemia and acute intermittent porphyria respectively; in both there is also a type caused by neoplasm-Di Guglielmo's disease and the porphyrin-producing hepatic adenoma (Tio, Leijnse, Jarrett and Rimington, 1957) respectively; in both there is a type caused by drugs: isoniazid-induced sideroblastic anaemia and hexachlorobenzene - induced cutaneous hepatic porphyria (Cetingil and Ozen, 1960).

\section{REFERENCES}

Bessis, M. C., and Breton-Corius, J. (1959): Ferritin and Ferruginous Micelles in Normal Erythroblasts and Hypochromic Hypersideraemic Anaemias, Blood, 14, 423.

BESSIS, M. C., and JENSEN, W. N. (1965): Sideroblastic Anaemia, Mitochondria and Erythroblastic Iron, Brit. J. Haemat, 11, 49.

BeSSIS, M., and CAROLI, J. (1959): A Comparative Study of Haemochromatosis by Electron Microscopy, Gastroenterology, 37, 538.

BISHOP, R. C., and BETHEL, F. H. (1959): Hereditary Hypochromic Anaemia with Transfusion Haemosiderosis Treated with Pyridoxine. Report of a Case, New Engl. J. Med., 261, 486.

Bizzozero, G. (1883): cited by P. Ehrlich. Zur Physiologie und Pathologie der Blut scheiben, Charité-Ann., 10, 136.

BJORKMAN, S. E. (1956): Chronic Refractory Anaemia with Sideroblastic Bone Marrow. A Study of Four Cases, Blood, 11, 250.

BOMFORD, R.' R., and RHOADS, C. P. (1941): Refractory Anaemia. I. Clinical and Pathological Aspects, Quart. J. Med. N.S., 10, 175.

Brain, M. C., and HerdaN, A. (1965): Tissue Iron
Stores in Sideroblastic Anaemia, Brit. J. Haemat., 11, 107.

BYRD, R. B., and COOPER, T. (1961): Hereditary Iron Loading Anaemia with Secondary Haemochromatosis, Ann. intern. Med., 55, 103.

CARLSON, H. B. (1956): Prophylaxis of Isoniazid Neuropathy with Pyridoxine, New Engl. J. Med., 255, 118.

CetingIL, A. I., and Ozen, M. A. (1960): Toxic Porphyria, Blood, 16, 1002.

COOLEY, T. B. (1945): A Severe Type of Hereditary Anaemia with Elliptocytosis. Interesting Sequence of Splenectomy, Amer. J. med. Sci., 209, 561.

COOPER, R. C., Webster, L. T., and Harris, J. W. (1963): A Role of Mitochondria in Iron Metabolism of Developing Erythrocytes (Abstract), J. Clin. Invest., 42, 926.

DACIE, J. V., and DONIACH, I. (1947): The Basophilic Property of Iron-containing Granules in Siderocytes, J. Path. Bact., 59, 684.

DACIE, J. V. (1954): The Haemolytic Anaemias: Congenital and Acquired, 2nd Ed., London: J. \& A. Churchill.

Dacie, J. V., SMith, M. D., White, J. C., and MolliN, D. L. (1959): Refractory Normoblastic Anaemia: A Clinical and Haematological Study of 7 Cases, Brit. J. Haemat., 5, 56.

DAGG, J. H., GoldBERG, A. LochHeAD, A., and SMirH, J. A. (1965): The Relationship of Lead Poisoning to Acute Intermittent Porphyria, Quart. J. Med., 34, 163.

DAMESHEK, W. (1965): Sideroblastic Anaemia. Is This Malignancy? Brit. J. Haemat., 11, 52. DoNIACH, J., GruNEBERG, H., and PEARSON, J. E. G
(1943): The Occurence of Siderocytes in Adu Human Blood, J. Path. Bact., 55, 23.

Douglas, A. S., and DACIE, J. V. (1953): The ${ }^{+}$ Incidence and Significance of Iron-containing Granules in Human Erythrocytes and their Precursors, J. clin. Path., 6, 307.

Garby, L., SJolin, S., and VaHLQuist, B. (1957): Chronic Refractory Hypochromic Anaemia with Disturbed Haem Metabolism, Brit. J. Haemat, 3, 55.

GelPI, A. P., and ENDE, B. (1958): An Hereditary Anaemia with Haemochromatosis. A Study of an Unusual Hemopathic Syndrome Resembling Thalassemia, Amer. J. Med., 25, 303.

GoldBerg, A., AsHenBruCKER, H., CarTwright, G. E., and WiNTROBE, M. M. (1956): Studies in the Biosynthesis of Haem in vitro by Avian Erythrocytes, Blood, 11, 821.

GolDBERG, A. (1965): Sideroblastic Anaemia: A Commentary, Brit. J. Haemat., 1, 114.

GrUNEBERG, H. (1941): Siderocytes: A New Kind of Erythrocytes, Nature (Lond.), 148, 144.

HARRISS, E. B., MACGibBon, B. H., and Mollin, $\frac{D}{0}$ D. L. (1965): Experimental Sideroblastic Anaemia,

11,99.
HeIlMerer, L., KeIderling, W., Belger, R., and N BERNAUER, H. (1958): Uber Chronische Refraktare N Anamien mit Sideroblastischen Knochermark N (Anaemia Refractoria Sideroblastica) Folia haemat. (Frankfurt) N.F., 2, 49.

HeILMEYER, L. (1960): Die Sideroachrestischen Anamien, Acta haemat. (Basel), 24, 19.

Heilmeyer, L., and ClotTen, R. (1961): Porphyrin $\stackrel{\oplus}{+}$ Metabolism in Anaemia, Panminerva med., p. 50. T HeILMEYER, L. (1964): Disturbances of Haem Synthesis, Springfield, Illinois: Charles C. Thomas. 
Kaplan, E., Zuelzer, W. W., and Mouriquand, C. (1954): Sideroblasts. A Study of Stainable Nonhaemoglobin Iron in Marrow Normoblasts, Blood, 9, 203.

Lichtman, H. C., and Feldman, F. (1963): In vitro Pyrolle and Porphyrin Synthesis in Lead Poisoning and Iron Deficiency, J. clin. Invest., 42, 830.

LochHeAD, A. C., and GoldberG, A. (1961): The Enzymic Formation of Haem by Human and Rat Tissue, Biochem. J., 78, 146.

LosowSKY, M. S., and HALL, R. (1965): Hereditary Sideroblastic Anaemia, Brit. J. Haemat., 1, 70.

LuDIN, H. (1957): Uber eine Neuartige Hypochrome Anaemie bei zwei Geschwistern auf der Grandlage einer Eisenverwertungs-storung. Anaemia Sideroachrestica Hereditaria, Schweiz. med Wschr., 87. 1237.

Lukl, P., WeIDermanN, B., and Borborik, M. (1958): Hereditare Leptocyten-anamie bei Mannern mit Hamochromatose, Folia Haemat. (Frankfurt) N.F., 3, 17.

Mills, H., and Lucia, S. P. (1949): Familial Hypochromic Anaemia Associated with Post-splenectomy Erythrocyte Inclusion Bodies, Blood, 4, 891

Mollin, D. L. (1965): Sideroblasts and Siderolastic Anaemia, Brit. J. Haemat., 11, 41.

Morse, W. I. (1955): Stainable Ferric Iron Particles in Erythroid Marrow Cells and Erythrocytes, Canad. med. Ass. J., 72, 418.

MOCURDY, P. R. (1963): INH Conditioned Pyridoxine Responsive Anaemia, Clin. Res., 11, 59.

MoFAdzeAN, A. J. S., and Davis, L. J. (1947): Iron Staining Erythrocytic Inclusions with Special Reference to Acquired Haemolytic Anaemia, Glasg. med. J., 28, 237.
MacGibbon, B. H., and Mollin, D. L. (1965): Sideroblastic Anaemia in Man: Observations on Seventy Cases, Brit. J. Haemat., 11, 59.

Redleaf, P. D. (1962): Pyridoxine-responsive Anaemia in a Patient Receiving Isoniazid, Dis. Chest., 42, 222.

ReDMOND, A. U. B., Robertson, J. H., and Nelson, M. G. (1963): Familial Hypochromic Anaemia with Hyperferricaemia. A Study of Two Families, Brit. med. J., ii, 89.

Rimington, C. (1958): The Biosynthesis of Haemoglobin, Proc. roy. Soc. Med., 51, 639.

RUNDles, R. W., and FAlls, H. F. (1946): Hereditary (? Sex-linked) Anaemia, Amer. J. med. Sci., 211, 641 .

Steiner, M., Baldini, M., and Dameshek, W. (1963): Heme Synthesis Defect in Refractory Anaemias with Ineffective Erythropoiesis, Blood, 22, 810 .

Tio, T. H., Leijnse, B., JARRETT, A., and Rimington, C. (1957): Acquired Porphyria from a Liver Tumour, Clin. Sci., 16, 517.

VAVRA, J. D. (1964): Heme and Porphyrin Synthesis in Refractory Sideroblastic Anaemia. Abstract $\mathbf{B}_{\mathbf{1 2}}$. $X$ th Congress of International Society of Haematology. Stockholm: Ljunglofs Litografiska AB.

Verloop, M. C., Bierenga, M., and DiezeraAd-NJoO, A. (1962): Primary or Essential Sideroachrestic Anaemias. Pathogenesis and Therapy, Acta haemat. (Basel), 27, 129.

Verwilghen, R., Reybrouk, G., Callens, L., and Cosemans, J. (1965): Antituberculous Drugs and Sideroblastic Anaemia, Brit. J. Haemat., 11, 92. 